\title{
Expression of transforming growth factor- $\beta$ isoforms and their receptors in utero-vaginal junction of hen oviduct in presence or absence of resident sperm with reference to sperm storage
}

\author{
Shubash Chandra Das, Naoki Isobe, Masahide Nishibori and Yukinori Yoshimura \\ Graduate School of Biosphere Science, Hiroshima University, Higashi-Hiroshima 739-8528, Japan \\ Correspondence should be addressed to Y Yoshimura; Email: yyosimu@hiroshima-u.ac.jp
}

\begin{abstract}
Our goal was to determine whether transforming growth factor $\beta$ (TGF $\beta$ ) isoforms were involved in the process of sperm survivability in the sperm-storage tubules (SST) in the utero-vaginal junction (UVJ) of hen oviduct. The birds were artificially inseminated. The mRNA expressions of three types of TGF $\beta$ isoforms (TGF $\beta 2$, TGF $\beta 3$, and TGF $\beta 4$ ) and three types of receptors (TRR1, TRR2, and T $\beta R 3$ ) were examined in the presence or in the absence of resident sperm in SST by semi-quantitative reverse transcriptase-PCR. The mRNA expression of TGF $\beta$ s and T $\beta$ Rs in sperm was also examined. Immunocytochemistry and western blot were performed for T $\beta R 2$ to confirm its localization in UVJ. The sperm were observed at least 10 days after insemination by histology. The mRNA expressions of TGF $\beta$ s and T $\beta$ Rs were significantly increased in UVJ in the presence of resident sperm in SST. The mRNA expressions of TGF $\beta$ s and T $\beta$ Rs were also observed in sperm. Immunohistochemistry revealed that T $\beta R 2$ were located in lymphocytes in UVJ and SST cells. The presence of T $\beta R 2$ in UVJ was also confirmed by western blot. These results suggest that enhanced expressions of TGF $\beta$ s and T $\beta$ Rs in UVJ may protect sperm in SST, probably by suppressing anti-sperm immunoreactions. Reproduction (2006) 132 781-790
\end{abstract}

\section{Introduction}

In hen oviduct, sperm are stored for a prolonged period in the sperm-storage tubules (SST) in the utero-vaginal junction (UVJ) and infundibulum with the UVJ as the primary site for sperm storage (Fujii \& Tamura 1963, Bobr et al. 1964, Bakst et al. 1994). The SST are formed by the invaginations of mucosal surface, where sperm are found to be close contact with the epithelium (Ashizawa \& Nishiyama 1983). A number of studies have examined the features of sperm survivability in SST, and suggested that quiescence of spermatozoa during the storage (Holm et al. 2000), interaction of SST fluid outflow from SST cells and sperm mobility (Froman 2003, Zaniboni \& Bakst 2004), and protection of sperm from immunoreaction (Das et al. 2005a, 2006) may be important events in this process. However, the precise mechanism of sperm survivability in the SST has not been established. There are reports that the leukocyte population was increased in UVJ after artificial insemination (AI) in infertile hens and the local immunity of vagina and UVJ may affect the sperm survivability (Higaki et al. 1995, Zheng et al. 2001, Das et al. $2005 b)$. Thus, one of the requirements for prolonged sperm survivability in hen oviduct may be to suppress the immune response to sperm stored in SST. Transforming growth factor $\beta$ (TGF $\beta$ ) is one of the possible factors to suppress immunoresponse (Wahl et al. 1988, Mouri et al. 2002). Apart from the basic functions affecting growth, differentiation, and morphogenesis of cells (Sporn et al. 1986, 1987), TGF $\beta$ isoforms mediate immunosuppression by suppressing the proliferation of T- and B-lymphocytes in mammals and birds (Kehrl et al. 1986a, 1986b, Quere \& Thorbecke 1990, Huang \& Huang 2005). TGF $\beta$ in human seminal plasma may protect sperm from immune response in female reproductive tract (Nocera \& Chu 1995, Srivastava et al. 1996). Thus, TGF $\beta$ s may play an important role in the storage of sperm in SST by suppressing anti-sperm immune response. Chicken TGF $\beta$ superfamily consists of TGF $\beta 2$, TGF $\beta 3$, and TGF $\beta 4$ (Chowdhury et al. 2003). Three types of TGF $\beta$ receptors, namely types 1,2 , and 3 (T $\beta R 1, T \beta R 2$, and $T \beta R 3$ ) were also identified in chicken (Chowdhury et al. 2004), and T $\beta R 2$ binds with TGF $\beta$ s directly and the complex is recognized by TRR1 (Massague 1996). However, the T $\beta R 3$ does not participate in signal transduction but increases the receptor-binding affinity and cell responsiveness (Lopez et al. 1993). 
Published information on the expression of TGF $\beta$ isoforms and their receptors in UVJ tissues or infundibulum are not available. If TGF $\beta$ s are involved in the protection of sperm from immunoreaction, the possibility of their synthesis by the sperm should also be examined. However, this possibility has also not been reported yet. Therefore, the goal of this study was to determine whether the cells in UVJ, and potentially the sperm themselves, express mRNAs of TGF $\beta$ isoforms and their receptors (TRRs) and whether their expressions are changed during the storage of sperm in SST. In Experiment 1, histological observations of UVJ tissue with or without Al were performed to confirm the changes in the population of SST-containing sperm and that of the lymphocytes after AI. In Experiment 2, mRNA expressions of TGF $\beta$ s and T $R$ Rs were investigated by reverse transcriptase (RT)-PCR. The expressions of TGF $\beta$ s and $T \beta R$ s by chicken sperm were also examined in Experiment 3. Finally, immunocytochemistry and western blot for T $\beta R 2$ were performed to localize it in UVJ in Experiment 4.

\section{Materials and Methods}

\section{Birds and tissue collection}

Healthy White Leghorn laying hens (aged approximately 50 weeks), regularly laying five or more eggs in a sequence were kept in individual cages under a regimen of $14 \mathrm{~h}$ light: $10 \mathrm{~h}$ darkness and provided with commercial feed and water ad libitum. The hens were inseminated in Experiments 1, 2, and 4, and examined at two different terms, namely short- (trial 1 ) and long term after Al (trial 2). In trial 1, the birds were divided into four groups: $0,1,12$, and $24 \mathrm{~h}$ after $\mathrm{Al}$ ( $n=4$ each). In trial 2, birds were also divided into four groups: 0,1 , 10 , and 20 days after $\mathrm{Al}$ ( $n=4$ each). Semen used for $\mathrm{Al}$ and RT-PCR analysis of TGF $\beta$ s and T $\beta$ Rs expressions in sperm (Experiment 3) was collected from White Leghorn roosters $(n=3)$ kept under the similar condition. For the insemination, $0.05 \mathrm{ml}$ undiluted fresh semen containing approximately $2 \times 10^{8}$ sperm were intravaginally introduced from the cloaca using a plastic syringe. When the oviductal tissues were collected, the birds were euthanatized by decapitation under anesthesia with Nembtal (Abbott Laboratories, IL, USA) after approximately $5 \mathrm{~h}$ oviposition. The handling of birds was performed in accordance with the regulation by Animal Experiment Committee of Hiroshima University.

\section{Experiment 1. Histological observation}

A part of UVJ tissues of all female birds (trials 1 and 2) were fixed with Bouin's solution followed by embedding in paraffin in the usual manner. Paraffin sections $(4 \mu \mathrm{m}$ in thickness) were prepared and stained with hematoxylin and eosin. The ratio of the SST-containing sperm and the lymphocyte frequencies in the lamina propria were analyzed under a light microscope with a computerassisted image analysis system (Image-Pro Plus; Media Cybernetics, Silver Spring, MD, USA) as described previously (Yoshimura et al. 2004). The lymphocytes were identified histologically with densely stained, small and round nuclei. Their frequencies in the lamina propria were analyzed by counting 15 different regions (approximately, $7-10 \times 10^{4} \mu^{2}$ area in each count) randomly selected from three UVJ sections. Then, the number of lymphocytes in $5 \times 10^{4} \mu \mathrm{m}^{2}$ areas was calculated.

\section{Experiment 2. RT-PCR analysis for expression of TGF $\beta$ s and $T \beta R$ s in UVJ}

Changes in the expressions for TGF $\beta$ s mRNA (TGF $\beta 2$, TGF $\beta 3$, and TGF $\beta 4$ ) and T $\beta$ Rs mRNA (T $\beta R 1, T \beta R 2$, and $T \beta R 3)$ after $A$ I were observed. In trial 1, four different oviductal segments, namely the infundibulum, uterus, UVJ, and vagina were collected. In trial 2, since significant changes in the expressions for TGF $\beta$ s and T $\beta$ Rs were observed only in UVJ in trial 1 , only the UVJ tissues were collected.

\section{Extraction of total RNA}

Total RNA was extracted from the mucosal tissues of oviductal segments using Sepasol RNA I Super (Nacalai Tesque, Inc., Kyoto, Japan) as described previously by Barua \& Yoshimura (2004). The pellet of RNA was suspended in TE buffer, incubated with DNase I (Roche) at a concentration of $10 \mathrm{U} / \mu \mathrm{l}$, and the RNA concentration was measured with Gene Quant Pro (Amersham Pharmacia Biotech), and stored at $-80{ }^{\circ} \mathrm{C}$ until analysis.

\section{Semi-quantitative RT-PCR}

The semi-quantitative RT-PCR was performed as described previously by Subedi \& Yoshimura (2005). The RNA samples were reverse transcribed using ReverTra Ace (Toyobo Co. Ltd, Osaka, Japan) as described by the manufacturer's instructions. The primers used for TGF 32 (Burt \& Paton 1991; Accession no. NM001031045), TGFß3 (Jakowlew et al. 1992; Accession no. S46000), and TGF $\beta 4$ (Jakowlew et al. 1988) and their receptors T $\beta R 1$ (Accession no. U38622), T $\beta R 2$ (Barnett et al. 1994; Accession no. NM205428), and T $\beta R 3$ (Barnett et al. 1994; Accession no. NM204339) and also for chicken $\beta$-actin (Kost et al. 1983; Accession no. X00182) are shown in Table 1. An aliquot of cDNA corresponding to $1 \mu \mathrm{g}$ initial total RNA was used as a template in a volume of $25 \mu \mathrm{l}$ reaction mixture for PCR. The mixture was denatured at $95^{\circ} \mathrm{C}$ for $1 \mathrm{~min}$ followed by 30 cycles of $95^{\circ} \mathrm{C}$ for $1 \mathrm{~min}, 58^{\circ} \mathrm{C}$ for $1 \mathrm{~min}$ to anneal, $72{ }^{\circ} \mathrm{C}$ for $1 \mathrm{~min}$ for extension and a final extension was done at $72{ }^{\circ} \mathrm{C}$ for $10 \mathrm{~min}$ in a Programmable Thermal Controller PTC-100 (MJ Research, Inc., Waltham, MA, 
Table 1 List of the PCR primers of TGF $\beta$ isoforms and their receptors.

\begin{tabular}{|c|c|}
\hline Primers & Sequences \\
\hline \multirow[t]{2}{*}{ TGF $\beta 2$} & F: 5'-AGGAATGTGCAGGATAATT-3' \\
\hline & R: 5'-ATTTTGGGTGTTTTGCCAA-3' \\
\hline \multirow{2}{*}{ TGF $\beta 3$} & F: 5'-CAGATCCTGGCGCTCTACA-3' \\
\hline & R: 5'-GAGGCCCTGGATCATGTCA-3' \\
\hline \multirow[t]{2}{*}{ TGF $\beta 4$} & F: 5'-CACCGACTACTGCTTCGGC-3' \\
\hline & R: 5'-GTCGGGCTCCAGATGTAC-3' \\
\hline \multirow[t]{2}{*}{ TRR1 } & F: 5'-GTTCCAAATGATCCCAGTT-3' \\
\hline & R: 5'-TGCTGATGGATTCTGATACC-3' \\
\hline \multirow[t]{2}{*}{ TRR2 } & F: 5'- CTATGCAAATTCTGTGACGTT - $3^{\prime}$ \\
\hline & R: 5' - ATCATCCTTCTTTTCCTTCAT -3' \\
\hline \multirow[t]{2}{*}{$\mathrm{T} \beta \mathrm{R} 3$} & F: 5'- TGCATGTCCTCAATCTCAGAA -3' \\
\hline & R: 5'- GCTGACAAAGAGAAAATTTCC - $3^{\prime}$ \\
\hline \multirow[t]{2}{*}{$\beta$-actin } & F: 5'-TTCCAGCCATCTTTCTTG-3' \\
\hline & R: 5'-TCCTTCTGCATCCTGTCA-3' \\
\hline
\end{tabular}

USA). In the preliminary experiments, different numbers of cycles $(25,30,35$, and 40 cycles) for TGF $\beta$ s and T $\beta$ Rs were tested in each sample to optimize the amplification and it was confirmed that 30 cycles were optimal for the detection of quantitative differences between the samples. The PCR products were electrophoresed in a $3 \%(\mathrm{w} / \mathrm{v})$ agarose gel with $0.4 \%$ ethidium bromide. The density of bands of TGF $\beta$ s and T $\beta$ Rs were quantified with reference to that of $\beta$-actin using a Gel-Pro analyzer (Media Cybernetics, Inc., Silver Spring, MD, USA), and the ratio of TGF $\beta$ s/ $\beta$-actin was obtained. The sequence of PCR products of TGF $\beta 2$, TGF $\beta 4$, T $\beta R 2$, and T $\beta R 3$ had been confirmed by our previous reports that used same primers as the present study (Chowdhury et al. 2003, 2004). The PCR products of TGF $\beta 3$ and T $\beta R 1$ were sequenced using the ExoSAP-IT (Amersham) and an ABI Prism BigDye Terminator Cycle Sequencing Kit (Amersham) as described by Nishibori et al. (2004). Sequences were analyzed with the GENETYX program package (version 7.04 Software Development, Tokyo, Japan). The sequence of PCR products corresponded to previous reports: TGF $\beta 2$ (Accession no. NM001031045), TGF 33 (Accession no. S46000),

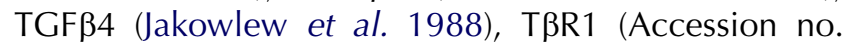
U38622), T $\beta R 2$ (Accession no. NM205428), and T $\beta R 3$ (Accession no. NM204339).

\section{Experiment 3. RT-PCR analysis for expression of TGF $\beta$ S and T $\beta R$ s by sperm}

A possibility of the expressions of TGF $\beta$ s and T $\beta$ Rs by sperm was examined. The sample of this experiment was fresh semen collected from roosters $(n=3)$. The semen $(0.5 \mathrm{ml})$ were added to $1 \mathrm{ml}$ PBS $(\mathrm{pH} 7.4)$ and centrifuged at $1700 \mathrm{~g}$ for $10 \mathrm{~min}$, and the precipitate containing sperm was washed three times with PBS by repeated centrifugation at $1700 \mathrm{~g}$ for $10 \mathrm{~min}$. The mRNA was isolated and RT-PCR analysis for the expressions of TGF $\beta$ s and T $\beta$ Rs was performed as described previously.

If the sperm express TGF $\beta$ s and T $\beta R$ s, expressions of TGF $\beta$ s and T $\beta R$ s in the UVJ-containing sperm in inseminated birds may be affected by sperm expression. It was examined whether the addition of sperm to isolated UVJ tissue causes the changes in their expression. Sperm were added to the isolated UVJ tissue at the ratio of $0,1.5 \times 10^{3}, 3 \times 10^{3}$, and $7.5 \times 10^{3} \mathrm{sperm} / \mathrm{mg}$ UVJ tissue, which is equivalent to $0,0.5,1$, and $2 \%$ of the inseminated sperm $\left(2 \times 10^{8}\right.$ sperm) that calculated based on the total UVJ mucosal tissue weight $(600 \mathrm{mg})$ respectively. However, Bakst et al. (1994) described the number of sperm that enter SST was $<1 \%$ of the inseminated sperm. Total mRNA was collected from the mixed samples and their expressions of TGF $\beta$ s and T $\beta$ Rs were observed in the same manner as described previously.

\section{Experiment 4. Immunohistochemistry and western-blot analysis for T $\beta R 2$}

Imunostaining for T $\beta R 2$ in the tissue of UVJ was performed using paraffin sections prepared in Experiment 1 . After deparaffinization, sections were washed with PBS for $15 \min (5 \min \times 3$ times), and autoclaved for $1 \mathrm{~min}$ in $2 \mathrm{mM}$ citric acid $(\mathrm{pH} 6.0)$ to enhance antigenicity. Then the sections were incubated overnight at $4{ }^{\circ} \mathrm{C}$ with sheep anti-chicken T $\beta R 2$ polyclonal antibody (Abcam Ltd, Cambridge, UK) diluted to 1:100 in PBS containing $0.05 \%$ BSA (Nacalai Tesque, Inc., Kyoto, Japan). After washing with PBS (5 min $\times 3$ times), the sections were incubated with biotinylated anti-sheep IgG (Abcam Ltd) for $1 \mathrm{~h}$ and with avidin-peroxidase complex (Nichirei Corporation, Tokyo, Japan) for $30 \mathrm{~min}$. The sections were washed in PBS $(5 \min \times 3$ times) and immunoprecipitates were visualized by incubating with $0.02 \%(\mathrm{w} / \mathrm{v}) 3^{\prime}, 3^{\prime}$-diaminobenzidine tetrahydrochloride (Nacalai Tesque, Inc., Kyoto, Japan) and $0.001 \%(\mathrm{v} / \mathrm{v}) \mathrm{H}_{2} \mathrm{O}_{2}$ in $0.05 \mathrm{M}$ Tris- $\mathrm{HCl}$ buffer $(\mathrm{pH}$ 7.6). The slides were counterstained with hematoxylin, dehydrated, and covered.

For western-blot analysis, the UVJ tissue of noninseminated birds and fresh sperm were homogenized in five times the volume of homogenization buffer consisting of $10 \mathrm{mM}$ Tris- $\mathrm{HCl}(\mathrm{pH}$ 7.4), $1 \mathrm{mM}$ ethylenediaminetetraacetic acid, and $1 \mathrm{mM}$ phenylmethylsulfonyl fluoride with a Polytron homogenizer (Kinematica AG, Littau, Lucerne, Switzerland). The samples were centrifuged at $12000 \mathrm{~g}$ for $10 \mathrm{~min}$, the supernatant was again centrifuged at $45000 \mathrm{~g}$ for $1 \mathrm{~h}$, and the supernatant was collected. The samples were separated by SDS-PAGE, $10 \%$ separating gel and $4 \%$ stacking gel, as described by Yoshimura et al. (1997). Briefly, the protein concentrations were measured using protein-assay reagent (Bio-Rad Lab.) as described by the manufacturer. Each sample of $62.5 \mu \mathrm{g}$ in $50 \mu \mathrm{l}$ was mixed with $20 \mu \mathrm{l}$ sample buffer $(35 \%(\mathrm{v} / \mathrm{v})$ glycerol, $12 \%(\mathrm{v} / \mathrm{v})$ mercaptoethanol, $7.2 \%(\mathrm{w} / \mathrm{v})$ SDS, $0.15 \mathrm{M}$ Tris- $\mathrm{HCl}(\mathrm{pH} 6.8)$, $0.06 \%(\mathrm{v} / \mathrm{v})$ bromophenol blue) and boiled for $2 \mathrm{~min}$. The sample, $10 \mu \mathrm{l}$, was loaded onto gels and run at $80 \mathrm{~V}$ 
in the stacking gel and at $120 \mathrm{~V}$ in the separating gel. After SDS-PAGE, the samples were electrophoretically transferred onto the nitrocellulose membrane (Hybond$\mathrm{C}$, Amersham Int.). The membrane was washed with western buffer (0.02 M Tris- $\mathrm{HCl}(\mathrm{pH} 7.4), 0.15 \mathrm{M} \mathrm{NaCl}$, $0.5 \%$ Tween-20, and $0.05 \%(\mathrm{w} / \mathrm{v}) \mathrm{BSA})$ for $30 \mathrm{~min}$ (10 min $\times 3$ times) and incubated with $10 \%$ Block Ace (Dainihon Pharmaceutical Co., Osaka, Japan) in western buffer for $30 \mathrm{~min}$. The membrane was then incubated with sheep anti-chicken T $\beta R 2$ polyclonal antibody (Abcam Ltd) diluted to 1:1000 with western buffer for overnight. Following washing with western buffer for $45 \mathrm{~min}$ ( $15 \mathrm{~min} \times 3$ times), they were incubated with biotinylated anti-sheep IgG (Abcam Ltd) diluted to 1:10 000 for $2 \mathrm{~h}$ and with avidin-peroxidase complex (Nichirei Co., Tokyo, Japan) for $1 \mathrm{~h}$. The membrane was washed with western buffer for $30 \mathrm{~min}(10 \mathrm{~min} \times 3$ times) and the immunoprecipates on the membrane were visualized by incubating in a reaction mixture of $0.02 \%(\mathrm{w} / \mathrm{v}) 3^{\prime}, 3^{\prime}$-diaminobenzidine tetrahydrochloride (Nacalai Tesque, Inc.) and $0.001 \%(\mathrm{v} / \mathrm{v}) \mathrm{H}_{2} \mathrm{O}_{2}$ in $0.05 \mathrm{M}$ Tris-HCl buffer ( $\mathrm{pH}$ 7.6).

\section{Statistical analysis}

The significance of differences in TGF $\beta$ s and T $\beta$ Rs expressions (the ratio of TGF $\beta$ s or $T \beta R s / \beta$-actin mRNAs) within each oviductal segment (infundibulum, uterus, UVJ, or vagina) was examined among different hours after Al (trial 1) or different days (trial 2) by oneway ANOVA, followed by Duncan's (1955) multiple range test. Differences were considered significant when $P$ value was $<0.05$.

\section{Results}

\section{Experiment 1. Histological observation}

In the UVJ, the SST were distributed in the lamina propria of mucosal folds. The SST consisted of single layer of non-ciliated epithelial cells. No sperm was observed in the lumen of SST in non-inseminated birds (Fig. 1A), whereas there were SST filled with sperm in the inseminated birds of trials 1 and 2 (Fig. 1B and C) except for 20 days after AI (Fig. 1D). The ratio of SST structure containing sperm was approximately $35-50 \%$ at 1,12 , and $24 \mathrm{~h}$ after $\mathrm{Al}$ (trial 1; Fig. 2A), and showed a gradual decrease on 10 days (trial 2; Fig. 2B). The number of lymphocytes in the stroma surrounding the SST was not changed significantly during experimental periods in both trials 1 and 2 (Fig. 2C and D).

\section{Experiment 2. RT-PCR analysis for expressions of TGF $\beta$ s and T $\beta R$ s in UVJ}

\section{Trial 1}

The expressions of TGF $\beta 2$, TGF $\beta 3$, and TGF $\beta 4$ were observed in the infundibulum, uterus, UVJ, and vagina. Figures 3-5 show the changes in the expressions of TGF $\beta s$ in the oviduct until $24 \mathrm{~h}$ after Al. Differences in the expressions for TGF $\beta 2$ were not significant among 0 , 1,12 , and $24 \mathrm{~h}$ after $\mathrm{Al}$ in the infundibulum, uterus, and vagina (Fig. 3A, B and D), however, that in the UVJ was significantly increased at $1 \mathrm{~h}$ after insemination and showed a gradual decreasing tendency (Fig. 3C). The expressions for TGF $\beta 3$ and TGF $\beta 4$ also did not show any significant changes within $24 \mathrm{~h}$ after $\mathrm{Al}$ in the infundibulum, uterus, and vagina (Figs $4 \mathrm{~A}, \mathrm{~B}$ and $\mathrm{D}$ and $5 \mathrm{~A}, \mathrm{~B}$

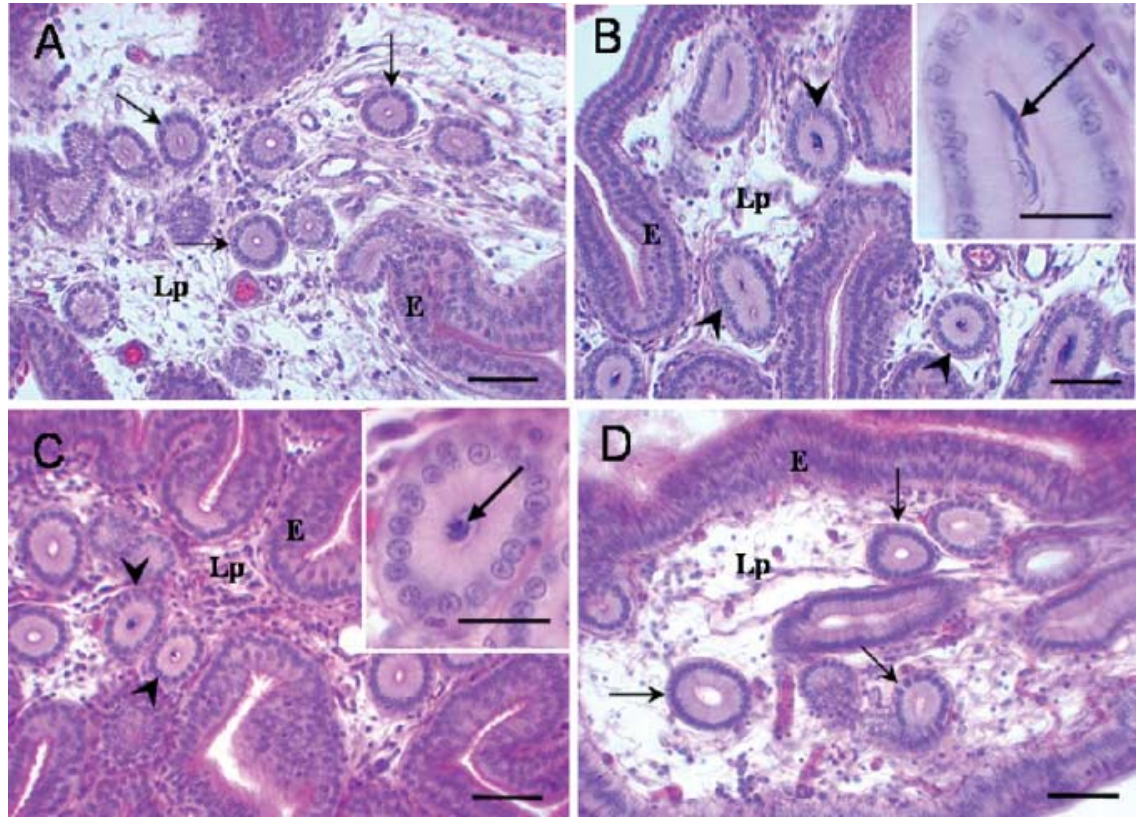

Figure 1 Sections of sperm-storage tubules (SST) in utero-vaginal junction of hens with or without insemination. (A) Before insemination. (B) 1 day after insemination. (C) 10 days after insemination. (D) 20 days after insemination. Note that SST are filled with sperm 1 and 10 days after insemination (arrow heads; (B) and (C)), whereas no sperm is located in SST before and 20 days after insemination (arrows; (A) and (D)). (E) Surface epithelium; $\mathrm{Lp}$, lamina propria; scale bars $=50 \mu \mathrm{m}$. HE staining. The inserts of (B) and (C) (scale bar, $20 \mu \mathrm{m}$ ) show the higher magnification of single SST with sperm in lumen (arrows). 

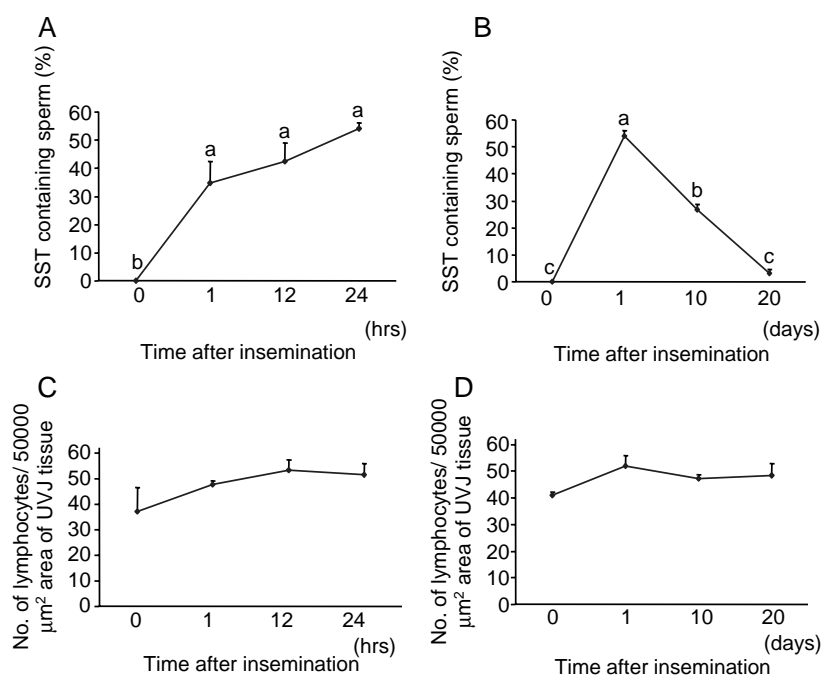

Figure 2 Frequency of SST-containing sperm and lymphocyte population in UVJ of non-inseminated and inseminated birds. (A) Frequency of SST with spermatozoa within $24 \mathrm{~h}$ after insemination. (B) Frequency of SST with spermatozoa within 20 days after insemination. (C) Number of lymphocytes in $50000 \mu \mathrm{m}^{2}$ areas of UVJ lamina propria within $24 \mathrm{~h}$ after insemination. (D) Number of lymphocytes in $50000 \mu \mathrm{m}^{2}$ areas of UVJ lamina propria within 20 days after insemination. Values represent the mean \pm S.E.M. $(n=4)$. Values with different superscripts are significantly different $(P<0.01)$.

and D). However, in UVJ, the expression of TGF $\beta 3$ was significantly increased during 1-12 h after $\mathrm{Al}$ and then decreased at $24 \mathrm{~h}$ after Al (Fig. 4C). The expression of TGF $\beta 4$ in UVJ was significantly greater during $1-24 \mathrm{~h}$ compared with the 0-h group (Fig. 5C).

The expressions of T $\beta R 1, T \beta R 2$, and T $\beta R 3$ were observed in the infundibulum, uterus, UVJ, and vagina.
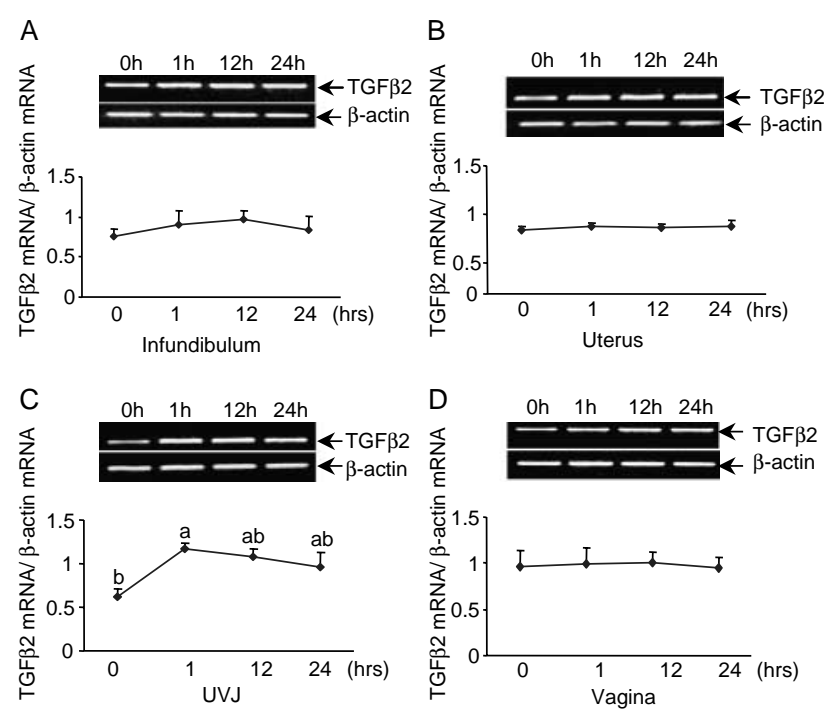

Figure 3 Changes in the expression of TGF $\beta 2$ in the tissues of (A) infundibulum, (B) uterus, (C) UVJ, and (D) vagina within $24 \mathrm{~h}$ after insemination. Values show the mean \pm S.E.M. ( $n=4$ for each value) of the ratio of TGF $\beta 2$ mRNA to $\beta$-actin mRNA. Values with different letters are significantly different $(P<0.05)$.
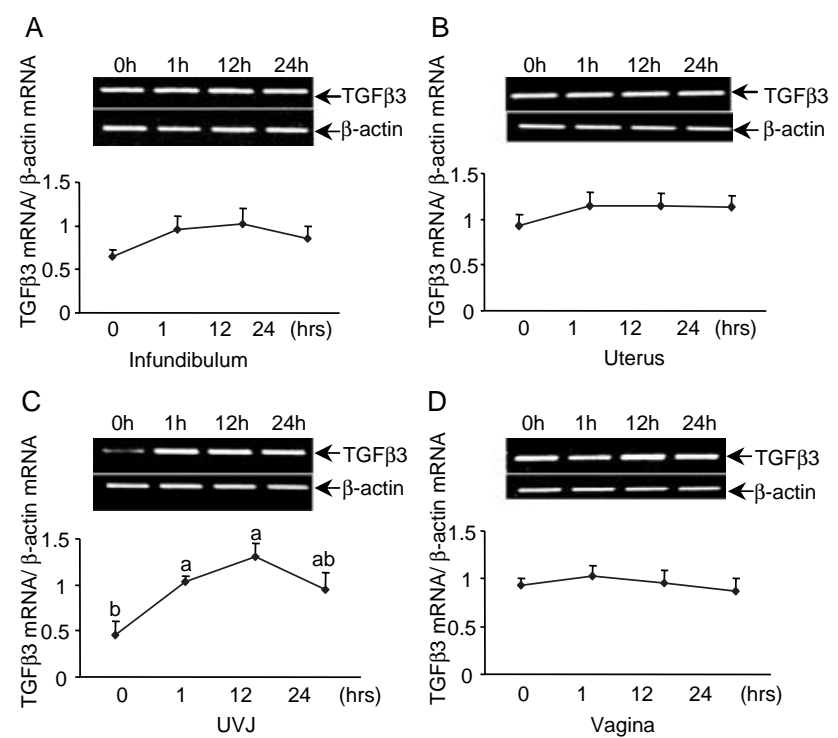

Figure 4 Changes in the expression of TGF $\beta 3$ in the tissues of (A) infundibulum, (B) uterus, (C) UVJ, and (D) vagina within $24 \mathrm{~h}$ after insemination. Values show the mean \pm s.E.M. ( $n=4$ for each value) of the ratio of TGF $\beta 3$ mRNA to $\beta$-actin mRNA. Values with different letters are significantly different $(P<0.05)$.

Differences in the expressions for $T \beta R 1$ and $T \beta R 2$ were insignificant among $0,1,12$, and $24 \mathrm{~h}$ after $\mathrm{Al}$ within the infundibulum, uterus, or vagina (Figs $6 \mathrm{~A}, \mathrm{~B}$ and $\mathrm{D}$ and $7 A, B$ and $D)$. In contrast, expressions of T $\beta R 1$ and T $\beta R 2$ in the UVJ were significantly increased at $1 \mathrm{~h}$ after $\mathrm{Al}$ and kept higher up to $24 \mathrm{~h}$ (Figs 6C and 7C). However, the expressions for $\mathrm{T} \beta \mathrm{R} 3 \mathrm{did}$ not show significant change within $24 \mathrm{~h}$ after $\mathrm{Al}$ in any of the oviductal segments observed in the present study (Fig. 8).
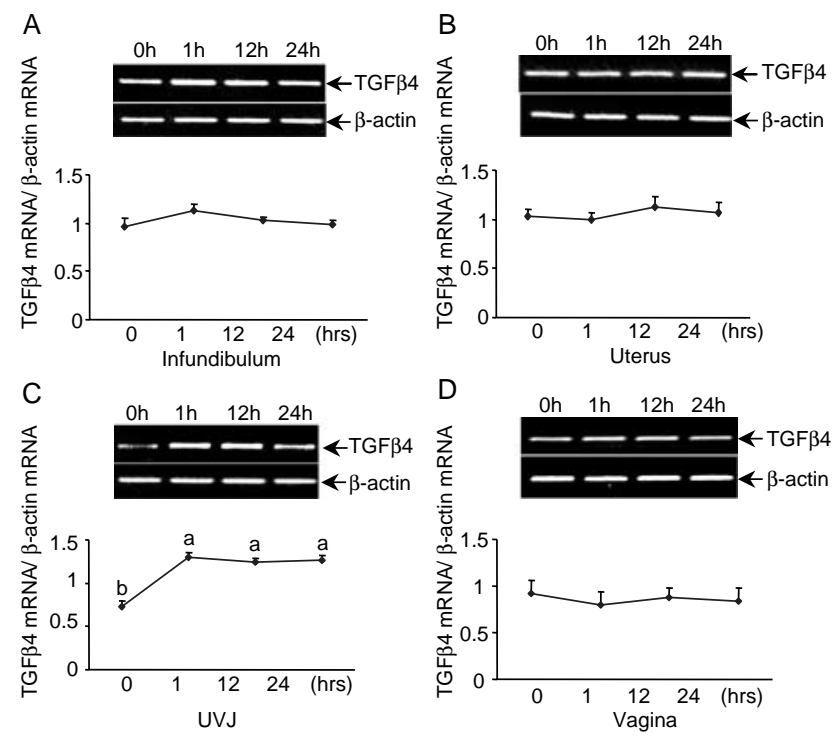

Figure 5 Changes in the expression of TGF 34 in the tissues of (A) infundibulum, (B) uterus, (C) UVJ, and (D) vagina within $24 \mathrm{~h}$ after insemination. Values show the mean \pm s.E.M. ( $n=4$ for each value) of the ratio of TGF $\beta 4$ mRNA to $\beta$-actin mRNA. Values with different letters are significantly different $(P<0.01)$. 

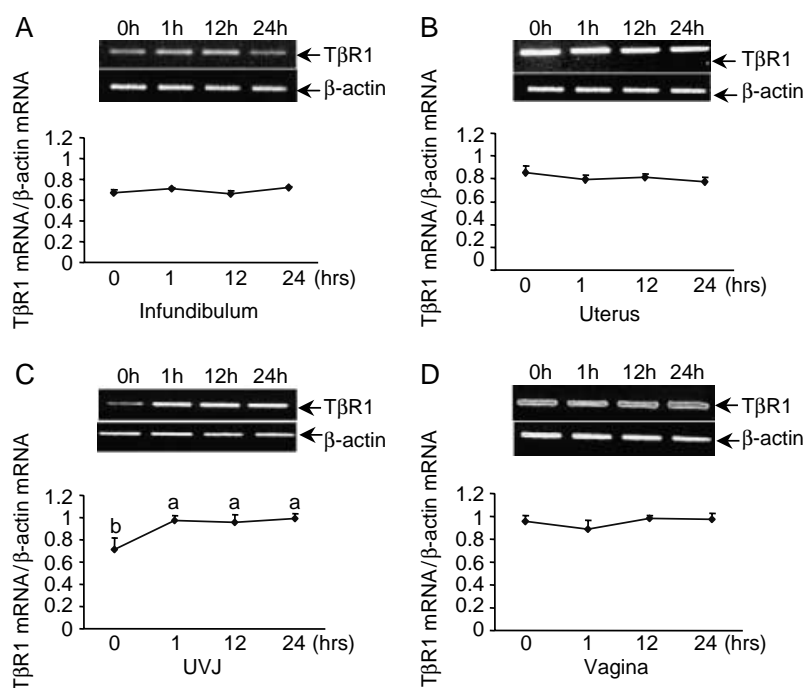

Figure 6 Changes in the expression of T $\beta R 1$ in the tissues of (A) infundibulum, (B) uterus, (C) UVJ, and (D) vagina within $24 \mathrm{~h}$ after insemination. Values show the mean \pm s.E.M. ( $n=4$ for each value) of the ratio of T $\beta R 1$ mRNA to $\beta$-actin mRNA. Values with different letters are significantly different $(P<0.05)$.

\section{Trial 2}

Figure 9 shows the changes in the expression of TGF $\beta$ s and their receptors in UVJ until 20 days after Al. Difference in the expression of TGF $\beta 2$ in UVJ was not significant among $0,1,10$, and 20 days after insemination (Fig. 9A). In contrast, the expression of TGF $\beta 3$ was significantly greater on 1 day after $\mathrm{Al}$ than 0 day and it returned to same level as 0-day group in 10 days (Fig. 9B). However, in case of TGF $\beta 4$, the expression was significantly increased on 1 day after $\mathrm{Al}$ compared with 0 day, and then gradually declined on 10 and 20 days (Fig. 9C).
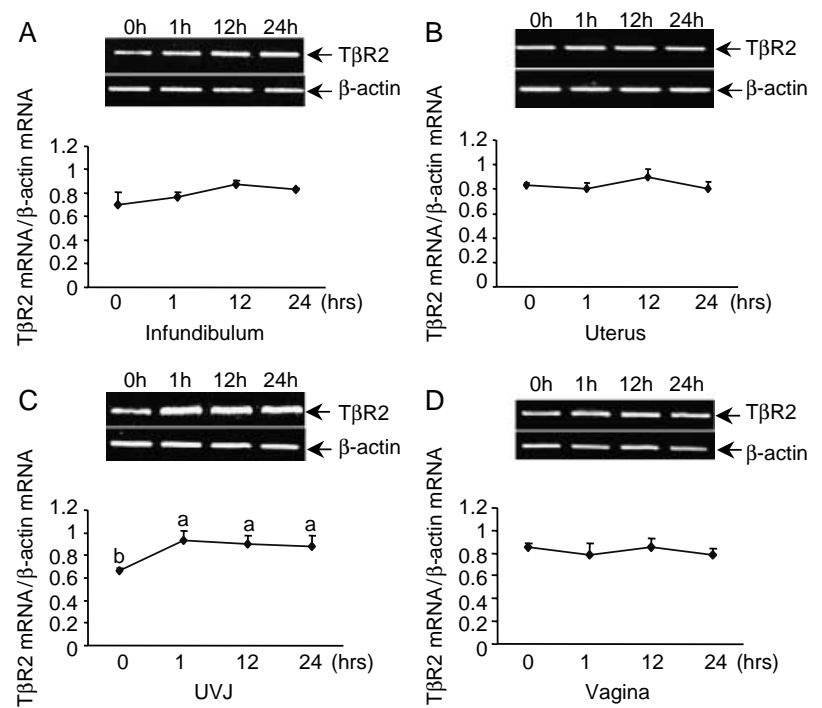

Figure 7 Changes in the expression of T $\beta R 2$ in the tissues of (A) infundibulum, (B) uterus, (C) UVJ, and (D) vagina within $24 \mathrm{~h}$ after insemination. Values show the mean \pm s.E.M. ( $n=4$ for each value) of the ratio of T $\beta R 2$ mRNA to $\beta$-actin mRNA. Values with different letters are significantly different $(P<0.05)$.
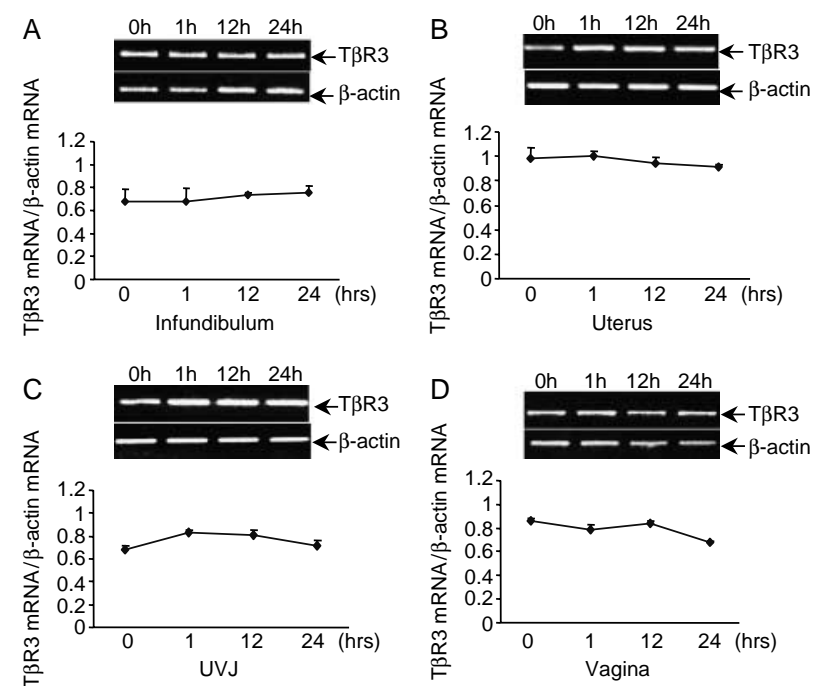

Figure 8 Changes in the expression of $T \beta R 3$ in the tissues of $(A)$ infundibulum, (B) uterus, (C) UVJ, and (D) vagina within $24 \mathrm{~h}$ after insemination. Values show the mean \pm S.E.M. ( $n=4$ for each value) of the ratio of T $\beta R 3$ mRNA to $\beta$-actin mRNA.
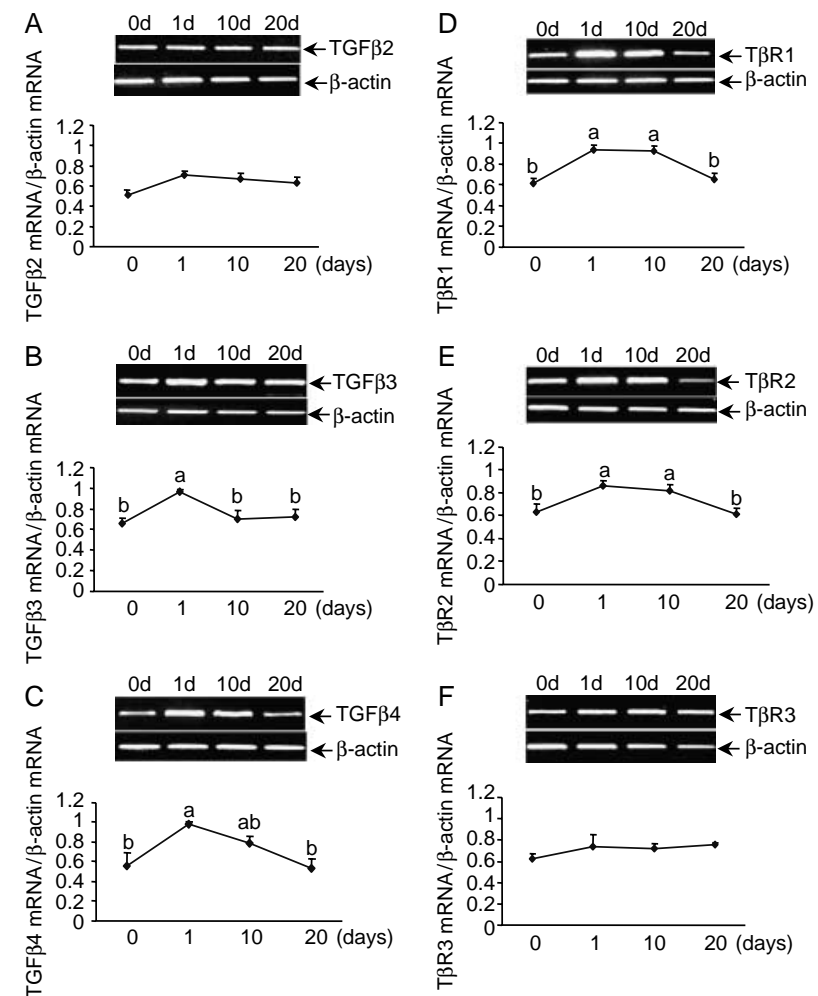

Figure 9 Changes in the expression of TGF $\beta$ isoforms and their receptors in the tissue of utero-vaginal junction within 20 days after insemination. (A) TGF $\beta 2$, (B) TGF $\beta 3$, (C) TGF $\beta 4$, (D) T $\beta R$ 1, (E) T $\beta R 2$, and (F) T $\beta R 3$. Values show the mean \pm s.E.M. ( $n=4$ for each value) of the ratio of TGF $\beta$ s or T $\beta$ Rs mRNA to $\beta$-actin mRNA. Values with different letters are significantly different $(P<0.05)$. 
The expressions of T $\beta R 1$ and T $\beta R 2$ in UVJ were significantly increased on 1 day after $\mathrm{Al}$ and kept higher until 10 days followed by decreasing on 20 days that showed a same level as 0 day (Fig. 9D and $E$ ). However, expression of TRR3 in the tissue of UVJ did not show any significant differences during 0-20 days (Fig. 9F).

\section{Experiment 3. Expression of TGF $\beta$ s and T $\beta$ Rs by sperm}

Clear PCR products showing the expression of the TGF $\beta 2$, TGF $\beta 3$, and TGF $\beta 4$ and T $\beta R 1, T \beta R 2$, and T $\beta$ R3 were observed in sperm samples (Fig. 10A and $\mathrm{B}$ ). The expressions of TGF $\beta$ s and T $\beta$ Rs were insignificant among the tissues of UVJ added with $0,1.5 \times 10^{3}, 3 \times 10^{3}$, and $7.5 \times 10^{3} \mathrm{sperm} / \mathrm{mg}$ UVJ tissue (Fig. 11).

\section{Experiment 4. Immunocytochemistry and western-blot analysis for $T \beta R 2$}

Immunoreactive T $\beta R 2$ were observed in the lymphocytes in the lamina propria (Fig. 12A). The cells in SST were also stained positive with a strong intensity as compared to those of the surface epithelium. Westernblot analysis confirmed the presence of T $\beta R 2$ in UVJ tissue and in sperm, which was observed approximately at $75 \mathrm{kDa}$ (Fig. 12B).

\section{Discussion}

We are reporting that the TGF $\beta$ s (TGF $\beta 2$, TGF $\beta 3$, and TGF $\beta 4$ ) and $T \beta R s$ (T $\beta R 1, T \beta R 2$, and $T \beta R 3$ ) are expressed in UVJ of hen oviduct and changed in association with the presence of sperm in the SST after Al. The significant findings of this study are: (i) among the four oviductal segments (infundibulum, uterus, UVJ, and vagina), the expressions for TGF $\beta$ s and T $\beta$ Rs were increased only in the tissue of UVJ during the storage of sperm in SST; (ii) the sperm also expressed TGF $\beta$ s and T $\beta R$ s; and (iii) lymphocytes and SST cells were immunopositive for T $\beta R 2$.

The expressions of TGF $\beta 2$, TGF $\beta 3$, and TGF $\beta 4$ in UVJ were significantly increased within $1 \mathrm{~h}$ after $\mathrm{Al}$ and that of TGF $\beta 4$ was kept higher even during $24 \mathrm{~h}-10$ days after Al. In case of their receptors, expressions of T $\beta R 1$ and

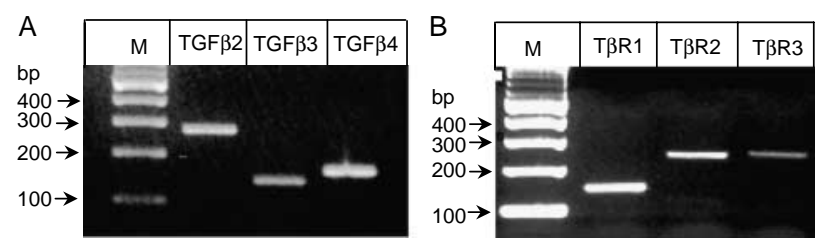

Figure 10 Expression of mRNAs of TGF $\beta$ isoforms and receptors by sperm. (A) M, marker; lane 2, TGF $\beta 2$; lane 3, TGF $\beta 3$; and lane 4, TGF $\beta 4$. (B) M, marker; lane 2, T $\beta R 1$; lane 3, T $\beta R 2$; and lane 4, T $\beta R 3$.
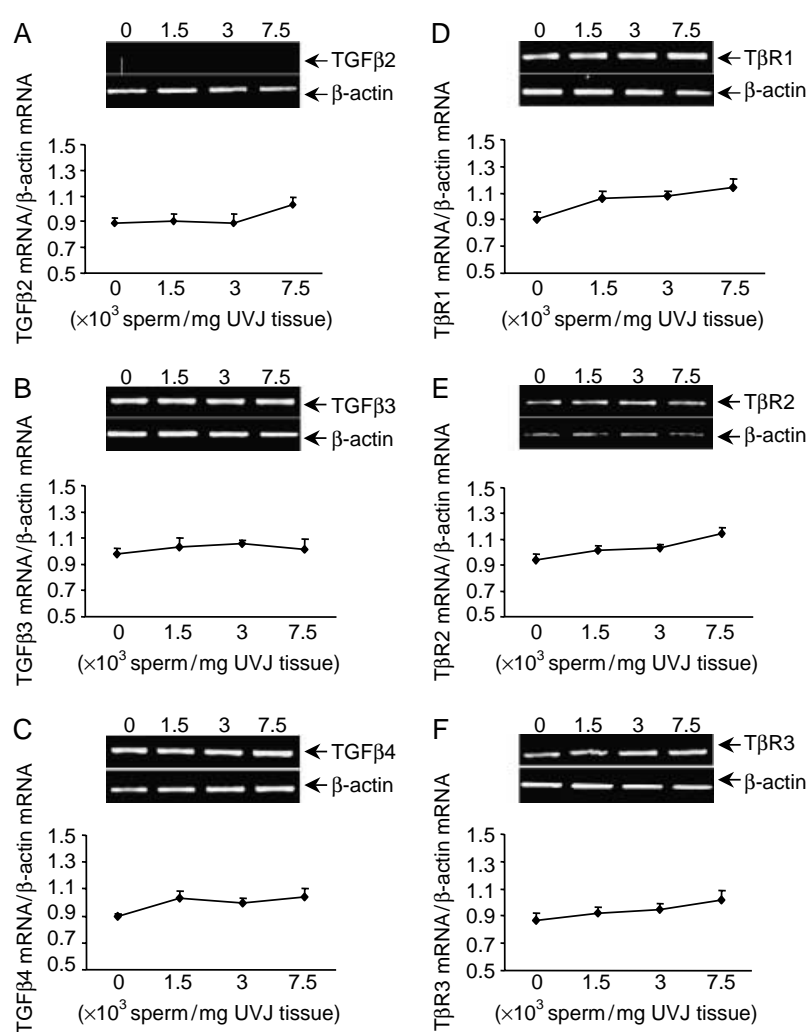

Figure 11 Changes in the expression of TGF $\beta$ isoforms and their receptors in the tissue of isolated utero-vaginal junction added with sperm. Sperm were added to UVJ mucosal tissue at the ratio of $0 \times 10^{3}$, $1.5 \times 10^{3}, 3 \times 10^{3}$, and $7.5 \times 10^{3} \mathrm{sperm} / \mathrm{mg}$ of UVJ tissue. (A) TGF $\beta 2$, (B) TGF $\beta 3$, (C) TGF $\beta 4$, (D) T $\beta R 1$, (E) T $\beta R 2$, and (F) T $\beta R 3$. Values show the mean \pm s.E.M. ( $n=4$ for each value) of the ratio of TGF $\beta$ s or T $\beta$ Rs mRNA to $\beta$-actin mRNA.

$T \beta R 2$ but not $T \beta R 3$ were increased at $1 \mathrm{~h}$ after $\mathrm{Al}$ and kept higher until 10 days. The UVJ is the primary site for sperm storage, where abundant SST distribute (Fujii \& Tamura 1963, Bakst et al. 1994). The ratio of SSTcontaining sperm was high on 1 day after $\mathrm{Al}$ and gradually decreased by 10 days, followed by decreasing to a negligible level on 20 days. Thus, there seems a close association between sperm storage and expressions levels of TGF $\beta$ s and their receptors. Among the three types of TGF $\beta$ s, the TGF $\beta 4$ isoform may be the most noticeable molecule for this event as it maintained higher expression level for the longest term, which was similar to the term of sperm residence in SST. In contrast, the other three oviductal segments, namely infundibulum, uterus, and vagina did not show increase in expressions for any of the ligands or their receptors. We suggest that increased expressions of TGF $\beta$ s and their receptors occur specifically in UVJ after insemination. The reason why the infundibulum, which is known as secondary sperm storage site, failed to show increase in expressions for any of the ligands or receptors may be due to that the amount of sperm storage in their SST is small. 
A

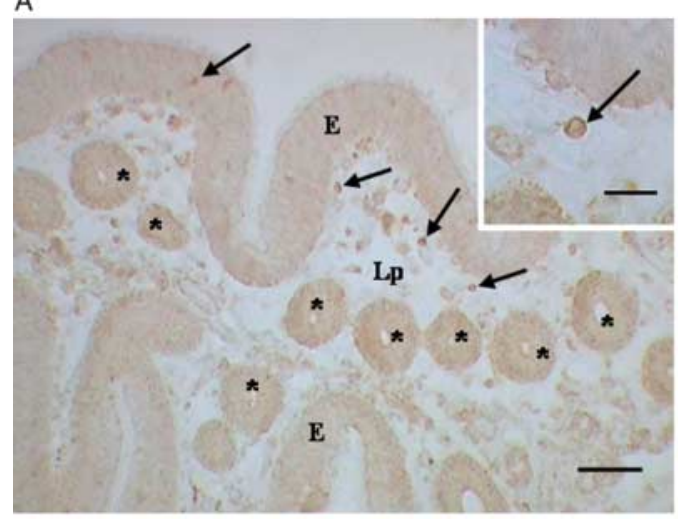

B

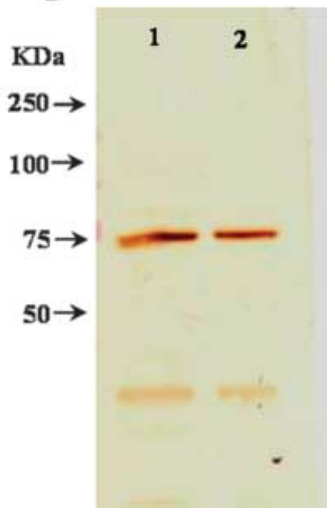

Figure 12 (A) Sections of utero-vaginal junction of an inseminated bird immunostained for T $\beta R 2$. Arrows indicate lymphocyte positive for T $\beta R 2$ in lamina propria and surface epithelium. SST cells also show positive staining. *, SST; E, surface epithelium; Lp, lamina propria. Scale bar $=40 \mu \mathrm{m}$. Inset shows magnified view of lymphocyte in the lamina propria. Scale bar $=10 \mu \mathrm{m}$. (B) Western blot of T $\beta R 2$ in the utero-vaginal junction of noninseminated laying hen and in sperm. The bands of approximately $75 \mathrm{kDa}$ are observed both in UVJ (lane 1) and sperm (lane 2).
We report the novel expressions of TGF $\beta 2$, TGF $\beta 3$, and TGF $\beta 4$, and T $\beta R 1, T \beta R 2$, and $T \beta R 3$ by chicken sperm observed in the present study. In the previous reports, TGF $\beta 1$ was detected in human sperm by immunostaining (Chu et al. 1996) and the presence of TGF $\beta 1$, TGF $\beta 2$, and TGF $\beta 3$ were identified in human seminal plasma (Nocera \& Chu 1995, Srivastava et al. 1996). It has also been reported that the majority of TGF $\beta$ in seminal fluids is in a latent form, which becomes activated in female reproductive tract after insemination (Robertson 2005). These results suggest that sperm likely produce TGF $\beta$ s in different species, including birds and mammals. However, the addition of $7.5 \times 10^{3}$ sperm to per milligram isolated mucosal UVJ tissue did not cause significant differences in the expression of TGF $\beta$ s and TßRs. Bakst et al. (1994) reported that the number of sperm that enter the SST is $<1 \%$, and approximately similar number of sperm were added to the UVJ tissue in this study. Therefore, the expressions of TGF $\beta$ s and T $\beta$ Rs in UVJ after AI might be increased by the interaction of SST cells and sperm, rather than the simple addition of sperm expression to the UVJ tissue expression. Sperm may influence some gene expressions and secretory proteomic profiles in the reproductive tract of mammals that may be related to sperm transport and selection (Fazeli et al. 2004, Georgiou et al. 2005). Long et al. (2003) reported the increase of gene expression for avidin in UVJ of turkey hens in response to insemination, and suggested that it might provide the nutrient sources of biotin or related vitamins for the resident sperm. These reports suggest that sperm may influence the gene expressions of some molecules in the oviduct of both mammals and birds. Thus, sperm could also induce the gene expression of TGF $\beta$ s and their receptors in the UVJ. The TGF $\beta$ s could be synthesized by sperm until ejaculation, however, it is not confirmed whether they are still synthesized even during the traveling in the oviduct. If sperm synthesize TGF $\beta$ s even while traveling the oviduc, it may play roles in protecting themselves.

Immunohistochemical examination confirmed the presence of T $\beta R 2$ in lymphocytes and SST cells, suggesting a possibility of interaction between TGF $\beta$ s and these cells. The specificity of the immunoreaction was confirmed by western-blot analysis. The TGF $\beta$ s and its receptors exert a potent inhibitory effect on B-cell proliferation and differentiation (Kehrl et al. 1986a). The TGF $\beta 1$ in mammalian species, which is thought to be an ortholog of TGF $\beta 4$ in avian species (Pan \& Halper 2003, Halper et al. 2004), suppressed immune response by maintaining development of suppressor T-cells in addition to the direct suppressive effect on the proliferation of B- and T-cells in chicken (Quere \& Thorbecke 1990). In a recent study, Huang \& Huang (2005) explained the involvement of T $\beta R$ - $V$-signaling cascade along with $T \beta R 1 / T \beta R 2$ for mediating the inhibitory function of TGF $\beta$ s on various type of cell proliferation. Thus, these reports suggest that TGF $\beta$ s exert suppressive effect on T- and B-cell proliferation or differentiation. Previous report described that lymphocyte population was increased in UVJ and sperm were not stored in SST in infertile hens after Al (Das et al. 2005b). Plasma cells were also shown in the UVJ of infertile hens (Van Krey et al. 1987). These results suggested that immune response to sperm may occur in infertile hens, resulting in the decline of sperm number stored in SST. Decline of fertility caused by immunoresponse to sperm has also been suggested in mammals (Mettler 1978). Our results showing the elevated levels of TGF $\beta$ s and the presence of $T \beta R 2$ in lymphocytes in UVJ suggest that TGF $\beta$ s produced by UVJ tissue and sperm may suppress immune response to sperm to maintain the survivability of them in the SST. In the present study with healthy hens, the population of stromal lymphocytes was not significantly different between inseminated and non-inseminated birds. We assume that this is the normal dynamics of lymphocytes in UVJ stroma in healthy birds and TGF $\beta$ might be involved in the suppression of increased lymphocyte population.

The SST cells showed the stronger immunoreactivity for T $\beta R 2$ than the surface epithelium of UVJ. Sperm expressed T $\beta R 1, T \beta R 2$, and $T \beta R 3$ with negligible immunoreactivity in SST on the immunostained sections, 
which might be due to the fewer amount of receptor molecules. The interaction of TGF $\beta$ s with the receptors in the SST cells and sperm may also be responsible for the survivability of sperm in SST.

In conclusion, we have provided evidence that the mRNA for TGF $\beta 2$, TGF $\beta 3$, and TGF $\beta 4$ and T $\beta R 1$, T $\beta R 2$, and $T \beta R 3$ are expressed in the hen oviduct and in sperm, and their expressions in UVJ are increased with Al. The increase of expressions in UVJ might be caused by the stimuli of sperm stored in SST. The enhanced expressions of TGF $\beta s$ and T $\beta R$ s in UVJ may be a mechanism responsible for the survivable of sperm during their storage in SST, probably via suppression of anti-sperm immunoreactions.

\section{Acknowledgements}

We are thankful to Dr A Barua, Department of Pharmacology, Rush University Medical Center, Chicago, IL, USA for reviewing the manuscript and put some valuable comments. This work was supported by a Grant-in-Aid for scientific research from the Ministry of Education, Science, Sports, and Culture of Japan to Y Yoshimura. The authors declare that there is no conflict of interest that would prejudice the impartiality of this scientific work.

\section{References}

Ashizawa K \& Nishiyama H 1983 Prolonged survival of fowl spermatozoa in the oviductal tissues in organ culture. British Poultry Science 24 27-32.

Bakst MR, Wishart G \& Brillard JP 1994 Oviductal sperm selection, transport, and storage in poultry. Poultry Science Review 5 117-143.

Barnett JV, Moustakas A, Lin W, Wang XF, Lin HY, Galper JB \& Mass RL 1994 Cloning and development expression of the chick type II and type III TGF $\beta$ receptors. Developmental Dynamics 199 12-24.

Barua A \& Yoshimura Y 2004 Changes in the expression of major histocompatability complex class II mRNA in response to inoculation with Salmonella enteritidis in cultured hen ovarian tissue. Journal of Poultry Science 41 281-288.

Bobr LW, Lorenz FW \& Ogasawara FX 1964 Distribution of spermatozoa in the oviduct and fertility in domestic birds. 1. Residence sites of spermatozoa in fowl oviducts. Journal of Reproduction and Fertility 8 39-47.

Burt DW \& Paton IR 1991 Molecular cloning and primary structure of the chicken transforming growth factor-beta 2 gene. DNA and Cell Biology 10 723-734.

Chowdhury VS, Nishibori M \& Yoshimura Y 2003 Changes in the expression of TGF $\beta$-isoforms in the anterior pituitary during withdrawal and resumption of feeding in hens. General and Comparative Endocrinology 133 1-7.

Chowdhury VS, Nishibori M \& Yoshimura Y 2004 Changes in the mRNA expression of TGF $\beta$ receptor types II and III in the anterior pituitary during induced molting in hens. Journal of Poultry Science 41 140-146.

Chu TM, Nocera MA, Flanders KC \& Kawinski E 1996 Localization of seminal plasma transforming growth factor- $\beta 1$ on human spermatozoa: an immunocytochemical study. Fertility and Sterility $\mathbf{6 6}$ $327-330$.

Das SC, Nagasaka N \& Yoshimura Y 2005a Effects of repeated artificial insemination on the structure and function of oviductal sperm storage tubules in hens. Journal of Poultry Science 42 39-47.
Das SC, Nagasaka N \& Yoshimura Y 2005b Changes in the localization of antigen presenting cells and T cells in the utero-vaginal junction after repeated artificial insemination in laying hens. Journal of Reproduction and Development 51 683-687.

Das SC, Nagasaka N \& Yoshimura Y 2006 Changes in the expression of estrogen receptor mRNA in the utero-vaginal junction containing sperm storage tubules in laying hens after repeated artificial insemination. Theriogenology 65 893-900.

Duncan B 1955 Multiple range and $F$ test. Biometrics 11 1-42.

Fazeli A, Affara NA, Hubank M \& Holt WV 2004 Sperm-induced modification of the oviductal gene expression profile after natural insemination in mice. Biology of Reproduction 71 60-65.

Froman D 2003 Deduction of a model for sperm storage in the oviduct of the domestic fowl (Gallus domesticus). Biology of Reproduction $61248-253$.

Fujii S \& Tamura T 1963 Location of sperms in the oviduct of the domestic fowl with special reference to storage of sperms in the vaginal gland. Journal of Faculty of Fisheries and Animal Husbandry, Hiroshima University 5 145-163.

Georgiou AS, Sostaric E, Wong CH, Snijders AP, Wright PC, Moore HD \& Fazeli A 2005 Gametes alter the oviductal secretory proteome. Molecular \& Cellular Proteomics 4 1785-1796.

Halper J, Burt DW \& Romanov MN 2004 On reassessment of the chicken TGF $\beta 4$ gene as TGF $\beta 1$. Growth Factors 22 121-122.

Higaki K, Yoshimura Y, Tamura T \& Okamoto T 1995 Localization of spermatozoa and leukocytes in vagina and utero-vaginal junction after copulation in Japanese quail (Coturnix coturnix japonica). Japanese Poultry Science 32 387-393.

Holm L, Ekwall H, Wishart GJ \& Ridderstrale Y 2000 Localization of calcium and zinc in the sperm storage tubules of chicken, quail and turkey using X-ray microanalysis. Journal of Reproduction and Fertility 118 331-336.

Huang SS \& Huang JS 2005 TGF- $\beta$ control of cell proliferation. Journal of Cellular Biochemistry 96 447-462.

Jakowlew SB, Dillard PJ, Sporn MB \& Roberts AM 1988 Complementary deoxyribonucleic acid cloning of a messenger ribonucleic acid encoding transforming growth factor $\beta 4$ from chicken embryo chondrocytes. Molecular Endocrinology 2 1186-1195.

Jakowlew SB, Lechleider R, Geiser AG, Kim SJ, Santa-Coloma TA, Cubert J, Sporn MB \& Roberts AB 1992 Identification and characterization of the chicken transforming growth factor- $\beta 3$ promoter. Molecular Endocrinology 6 1285-1298.

Kehrl JH, Roberts AB, Wakefield LM, Jakowlew S, Sporn MB \& Fauci AS 1986a Transforming growth factor $\beta$ is an important immunomodulatory protein for human B lymphocytes. Journal of Immunology 137 3855-3860.

Kehrl JH, Wakefield LM, Roberts AB, Jakowlew S, Alvarez-Mon M, Derynck R, Sporn MB \& Fauci AS 1986b Production of transforming growth factor $\beta$ by human T lymphocytes and its potential role in the regulation of T cell growth. Journal of Experimental Medicine 163 1037-1050.

Kost TA, Theodorakis N \& Hughes SH 1983 The nucleotide sequence of the chick cytoplasmic $\beta$-actin gene. Nucleic Acids Research $\mathbf{1 1}$ 8287-8301.

Long EL, Sonstegard TS, Long JA, Van Tassell CP \& Zuelke KA 2003 Serial analysis of gene expression in turkey sperm storage tubules in the presence and absence of resident sperm. Biology of Reproduction 69 469-474.

Lopez CF, Wrana JL \& Massague J 1993 Beta-glycan presents legand to the TGF $\beta$ signaling receptor. Cell 73 1435-1444.

Massague J 1996 TGF $\beta$ signaling: receptors, transducers, and mad proteins. Cell 85 947-950.

Mettler L 1978 Humoral and cellular immune response to sperm and platental antigens as causal factors of female sterility and infertility. Andrologia 10250.

Mouri H, Sakaguchi K, Sawayama T, Senoh T, Ohta T, Nishimura M, Fujiwara A, Terao M, Shiratori Y \& Tsuji T 2002 Suppressive effects 
of transforming growth factor- $\beta 1$ produced by hepatocellular carcinoma cell lines on interferon-gamma production by peripheral blood mononuclear cells. Acta Medica Okayama 56 309-315.

Nishibori M, Hayashi T \& Yasue H 2004 Complete nucleotide sequence of Numida meleagris (Helmeted Guineafowl) mitochondrial genome. Journal of Poultry Science 41 259-268.

Nocera M \& Chu TM 1995 Characterization of latent transforming growth factor- $\beta$ from human seminal plasma. American Journal of Reproductive Immunology and Microbiology 33 282-291.

Pan H \& Halper J 2003 Cloning, expression, and characterization of chicken transforming growth factor $\beta 4$. Biochemical and Biophysical Research Communications 303 24-30.

Quere P \& Thorbecke GJ 1990 Multiple suppressive effects of transforming growth factor $\beta 1$ on the immune response in chickens. Cellular Immunology 129 468-477.

Robertson SA 2005 Seminal plasma and male factor signaling in the female reproductive tract. Cell and Tissue Research 322 43-52.

Sporn MB, Roberts AB, Wakefield LM \& Assoian RK 1986 Transforming growth factor- $\beta$ : biological function and chemical nature. Science $233532-534$.

Sporn MB, Roberts AB, Wakefield LM \& de Crombrugghe B 1987 Some recent advances in the chemistry and biology of transforming growth factor- $\beta$. Journal of Cell Biology 105 1039-1045.

Srivastava MD, Lippes J \& Srivastava BI 1996 Cytokines of the human reproductive tract. American Journal of Reproductive Immunology 36 157-166.

Subedi K \& Yoshimura Y 2005 Expression of MHC class I and II in growing ovarian follicles of young and old Laying hens, Gallus domesticus. Journal of Poultry Science 42 101-109.
Van Krey HP, Schuppin GT, Denbow DM \& Hulet RM 1987 Turkey breeder hen infertility associated with plasma cells in the uterovaginal sperm storage glands. Theriogenology 27 913-921.

Wahl SM, Hunt DA, Wong HL, Dougherty S, McCartney-Francis N, Wahl LM, Ellingsworth L, Schmidt JA, Hall G \& Roberts AB 1988 Transforming growth factor- $\beta$ is a potent immunosuppressive agent that inhibits IL-1-dependent lymphocyte proliferation. Journal of Immunology 140 3026-3032.

Yoshimura Y, Ohira H \& Tamura T 1997 Immunocytochemical localization of vitamin D receptors in the shell gland of immature, laying and molting hens. General and Comparative Endocrinology 108 282-289.

Yoshimura Y, Tamura Y, Liang JX \& Okamoto T 2004 Immunolocalization of lymphocyte subsets in the testis and epididymis of roosters. Journal of Poultry Science 41 315-321.

Zaniboni L \& Bakst MR 2004 Localization of aquaporins in the sperm storage tubules in the turkey oviduct. Poultry Science 83 1209-1212.

Zheng WM, Nishibori M, Isobe N \& Yoshimura Y 2001 An in situ hybridization study of the effect of artificial insemination on the localization of cells expressing MHC class II mRNA in the chicken oviduct. Reproduction 122 581-586.

Received 9 March 2006

First decision 17 May 2006

Revised manuscript received 26 June 2006

Accepted 27 July 2006 